\title{
Retraction \\ Retracted: Recent Trends of Polymer Mediated Liposomal Gene Delivery System
}

\author{
BioMed Research International \\ Received 3 July 2019; Accepted 3 July 2019; Published 8 August 2019 \\ Copyright (C) 2019 BioMed Research International. This is an open access article distributed under the Creative Commons \\ Attribution License, which permits unrestricted use, distribution, and reproduction in any medium, provided the original work is \\ properly cited.
}

BioMed Research International has retracted the article titled "Recent Trends of Polymer Mediated Liposomal Gene Delivery System" [1]. The article was found to contain a substantial amount of material from a number of published articles, including the following sources:

(i) L. E. van Vlerken, T. K. Vyas, and M. M. Amiji, "Poly(ethylene glycol)-Modified Nanocarriers for TumorTargeted and Intracellular Delivery," Pharmaceutical Research, vol. 24, no. 8, pp. 1405-1414, 2007, https://doi.org/10 .1007/s11095-007-9284-6 [2] (cited as [98]).

(ii) Daniel A. Balazs and WT. Godbey, "Liposomes for Use in Gene Delivery," Journal of Drug Delivery, vol. 2011, Article ID 326497, 12 pages, 2011, https://doi.org/10.1155/ 2011/326497 [3] (not cited).

(iii) Vladimir P. Torchilin, "Recent Advances with Liposomes as Pharmaceutical Carriers," Nature Reviews Drug Discovery, vol. 4, no. 2, pp. 145-160, 2005, https://doi.org/ 10.1038/nrd1632 [4] (cited as [35]).

(iv) Arcadio Chonn and Pieter R Cullis, "Recent Advances in Liposome Technologies and Their Applications for Systemic Gene Delivery," Advanced Drug Delivery Reviews, 1998, https://doi.org/10.1016/S0169-409X(97)00108-7 [5] (not cited).

(v) Marika Ruponen, Seppo Ylä-Herttuala, and Arto Urtti, "Interactions of Polymeric and Liposomal Gene Delivery Systems with Extracellular Glycosaminoglycans: Physicochemical and Transfection Studies," Biochimica et Biophysica Acta: Biomembranes, vol. 1415, no. 2, pp. 331-341, 1999, https://doi.org/10.1016/S0005-2736(98)00199-0 [6] (cited as [138]).

The authors do not agree to the retraction.

\section{References}

[1] S. K. Kundu, A. R. Sharma, S. S. Lee et al., "Recent trends of polymer mediated liposomal gene delivery system," BioMed
Research International, vol. 2014, Article ID 934605, 15 pages, 2014.

[2] L. E. van Vlerken, T. K. Vyas, and M. M. Amiji, "Poly(ethylene glycol)-modified nanocarriers for tumor-targeted and intracellular delivery," Pharmaceutical Research, vol. 24, no. 8, pp. 14051414, 2007.

[3] D. A. Balazs and W. T. Godbey, "Liposomes for use in gene delivery," Journal of Drug Delivery, vol. 2011, Article ID 326497, 12 pages, 2011.

[4] K.-L. Kuo and D.-C. Tarng, "Oxidative stress in chronic kidney disease," Adaptive Medicine, vol. 2, no. 2, pp. 87-94, 2010.

[5] A. Chonn and P. R. Cullis, "Recent advances in liposome technologies and their applications for systemic gene delivery," Advanced Drug Delivery Reviews, vol. 30, no. 1-3, pp. 73-83, 1998.

[6] M. Ruponen, S. Ylä-Herttuala, and A. Urtti, "Interactions of polymeric and liposomal gene delivery systems with extracellular glycosaminoglycans: Physicochemical and transfection studies," Biochimica et Biophysica Acta (BBA) - Biomembranes, vol. 1415, no. 2, pp. 331-341, 1999. 